\title{
Compassionate conservation, rehabilitation and translocation of Indonesian slow lorises
}

\author{
R. S. Moore ${ }^{1,2}$, Wihermanto ${ }^{2}$, K. A. I. Nekaris ${ }^{1, *}$ \\ ${ }^{1}$ Nocturnal Primate Research Group, Oxford Brookes University, Oxford OX3 0BP, UK \\ ${ }^{2}$ International Animal Rescue, Ciapus Primate Centre, PO Box 125, Bogor 16001, Indonesia \\ ${ }^{3}$ Pusat Konservasi Tumbuhan, Kebun Raya Bogor, Bogor 16003, Indonesia
}

\begin{abstract}
With the number of threatened species in rescue centres rising, scientific reports on the functioning and success of such centres is essential. Compassionate conservation tries to bridge the gap between animal welfare advocates and conservation biologists, recognising the benefits of preserving a species and its individuals. A case in point is that of Indonesia's threatened slow lorises Nycticebus spp., where illegal trade is decimating wild populations of these primates. We present $4 \mathrm{yr}$ of data from Ciapus Primate Centre in Indonesia, which received 180 slow lorises between 2008 and 2011 . We show that $>85 \%$ of these primates were unsuitable for reintroduction; 23 slow lorises that were deemed suitable for reintroduction were released to the wild between 2010 and 2013 and were followed with radio tracking. Eleven of them died (on average $76 \mathrm{~d}$ post-release), 1 was recaptured (148 d post-release), 6 are no longer being monitored (after, on average, $263 \mathrm{~d}$ post-release) and their status is unknown, and 5 are still being monitored (average 226 d post-release, as of December 2013). The challenges posed by work with slow lorises in the Ciapus Primate Centre over these 4 yr, with release success highly variable, show that even with concerted effort, rescue centres need to consider alternative options. We review such options, considering the pros and cons of euthanasia, life in captivity and reintroduction to the wild. We conclude that in today's global conservation crisis, it can only be beneficial to combine the expertise of animal welfare practitioners and conservation biologists.
\end{abstract}

KEY WORDS: Nycticebus coucang $\cdot$ Nycticebus javanicus $\cdot$ Slow loris $\cdot$ Rescue centre $\cdot$ Euthanasia Conservation

\section{INTRODUCTION}

The numbers of threatened animal species housed in rescue centres around the world are on the rise (Cheyne 2006, Nijman 2009). Whilst habitat loss is a prominent factor in the decline of many species, the impact of trade - both legal and illegal - is underestimated (Shepherd et al. 2004, Nijman 2010). When confiscations are made of animals from trade, their most likely terminus is either government holding facilities, zoos, or rescue centres (Nijman et al. 2009). Depending on availability of space, suitable housing and funding at such centres, animals may face:

\footnotetext{
${ }^{*}$ Corresponding author: anekaris@brookes.ac.uk
}

euthanasia, a lifetime in captivity, or reintroduction to the wild (Harcourt 1987, Cooper \& Cooper 2006). Deciding on which option to take can raise controversial and conflicting opinions, depending on the intentions of those involved (Harcourt 1987, IUCN 2002b).

Of the species affected by trade, primates are among the most ubiquitous (Shepherd 2010, Nijman et al. 2011). In 2008, a rescue centre was established in Bogor, Java, by International Animal Rescue (IAR) to accommodate displaced Indonesian primates: macaques (Macaca fascicularis and $M$. nemestrina) and slow lorises (Nycticebus coucang, $N$. menagensis and N. javanicus). Slow lorises, nocturnal strep-

() The authors 2014. Open Access under Creative Commons by Attribution Licence. Use, distribution and reproduction are unrestricted. Authors and original publication must be credited. 
shirrine primates, are under particular pressure from trade, regularly appearing in the region's animal markets owing to their high demand as pets and for traditional medicine (Shepherd et al. 2004, Nekaris et al. 2009, Starr et al. 2010). In 2007, Nycticebus was transferred to CITES (Convention on International Trade in Endangered Species of Wild Fauna and Flora) Appendix 1, banning all international commercial trade. Despite efforts to improve law enforcement and raise international awareness, there is no apparent sign of this trend slowing down (Cheyne 2006, Nijman et al. 2009, Nekaris et al. 2010, Starr et al. 2010). In Indonesia, for example, trade in slow lorises and other low-profile protected species persists openly in numerous bird markets. The traders' absence of fear of legal action suggests adequate enforcement is lacking (Nijman 2009, Shepherd 2010).

Rescue centres primarily function to rehabilitate wild animals, and they undoubtedly possess a vast potential to engage in conservation and welfare of displaced animals (Teleki 2001, Cheyne 2006, Beck 2010). Rescue and rehabilitation centres are linked to the level of law enforcement in a country (Rijksen \& Meijaard 1999). The sheer volume of animals in trade, however, ensures most rescue centres reach carrying capacity within 1 to 2 yr (Bennett 1992, Teleki 2001, Ware 2001, Nijman et al. 2009). The process of trial and error is often repeated every time a new centre is established (Teleki 2001). The goals of each centre are determined by the owners - often based on personal judgement-in isolation from other centres (Teleki 2001, Carter 2003, Farmer \& Courage 2008). Some authors have criticised the methods employed by rescue centres, without offering practical alternatives (Teleki 2001, Carter 2003). Arguments often stem from the fields of conservation biology and animal welfare science, whereby the former focuses on assisting the plight of the species and the latter, on the welfare of the individual (Fraser 1999, Albrecht 2003, Kabasawa 2011). Some conservation biologists assert that rescue centres squander funding that could be better used elsewhere (MacKinnon 1977, Bennett 1992, Ware 2001, Carter 2003, Kabasawa 2011). Cheyne (2006) indicates that funding for conservation and welfare is usually derived from different sources. Compassionate conservation has developed as a discipline attempting to bridge the divide between the conservation of a species and animal welfare on an individual level (Ramp 2013). This discipline seeks to identify, enhance and promote the commonalities between animal welfare and conservation; pursue, as far as possible, the best practice in these disciplines; and work to achieve shared principles (Bekoff 2013a).

The topics of reintroduction ('the intentional movement and release of an organism inside its indigenous range from which it has disappeared') and translocation ('the human-mediated movement of living organisms with release in another') (IUCN/SSC 2013) of animals often raise controversies relating to the viability of success in such projects and the issues of animal welfare post-release (Soorae 2008). A major criticism of translocation programmes is the lack of documentation and subsequent publication of results in the scientific community (Beck et al. 1994, Yeager \& Silver 1999, Fischer \& Lindenmayer 2000, Carter 2003). The reasons for lack of communication appear to be related to fear of condemnation by authorities or funding agencies as a result of the failure or improper implementation of such projects (Teleki 2001, Farmer \& Courage 2008). Nevertheless, without such information, progress in the field of reintroduction science will undoubtedly be hampered by a lack of comparable data - both successful and unsuccessful - from which modifications can be made accordingly (Fischer \& Lindenmayer 2000, Seddon et al. 2007).

Using the case of Indonesian slow lorises as an example, we provide a case study from IAR's Ciapus Primate Centre (CPC). We review the demographic trends of slow lorises that have arrived at the centre since its opening in 2006, until 2011, including their origins, condition and mortality. We present the methods and results of translocations of slow lorises over an 18 mo period. With many animals unable to be released owing to various health and behavioural defects, a question is raised: What is the most viable option regarding both conservation and animal welfare for animals that cannot be released? We tackle this question of compassionate conservation and relate it to current welfare and conservation goals.

\section{MATERIALS AND METHODS}

Since the CPC was established in 2006, animal records have been compiled in a database including information on species, sex, origin and condition on arrival. Four different categories were used for classifying the origin of the animal: captive-born, confiscations, transit and surrendered. Some slow lorises (Nycticebus spp.) were born whilst at the CPC; as slow lorises are provided with contraceptive drugs, births usually only occur if the animal is pregnant on 
arrival. Confiscations were defined as police raids on pet markets. Transit raids were also police confiscations, but occurred before the animals reached their market destination. Only 1 prosecution ever occurred for all confiscated or raided animals. Surrendered animals were obtained from people who bought an animal and subsequently donated it to the CPC, either because they discovered it was illegal or beacause they no longer wanted it. When possible, the people surrendering the slow lorises were questioned. Questions included: reason for buying, market price and reason for surrendering. These data were analysed using Microsoft Excel and SPSS 17.

In 2010, the CPC began a systematic translocation programme for the Critically Endangered Javan slow loris $N$. javanicus and Vulnerable greater slow loris $N$. coucang. These translocations, made into an area where wild slow lorises still occurred, can be considered conservation translocations to reinforce an existing population of conspecifics (Seddon et al. 2012). The CPC followed, wherever possible, 'The Guidelines for Reintroductions and other Conservation Translocations of Primates' (IUCN 2002a); we note, however, that it was not possible to follow several recommendations. No studies of the behaviour and ecology of Indonesian slow lorises had been made, so knowledge of diet, relationship with predators, or home range size was not available. Health checks of the existing wild population were not made. The taxonomy of Bornean and greater slow lorises has been under revision (e.g. Munds et al. 2013), and species identity was checked using morphological criteria only for those species listed on the IUCN Red List and not, for instance, using genetic markers or morphological criteria for putative new species.

Established pre- and post-release protocols were adhered to as far as possible, and included a $6 \mathrm{wk}$ quarantine period for all new arrivals, health checks and disease screening, behavioural assessments and development of natural behaviours via enrichment (Reading et al. 2013), habitat evaluation at the proposed release site, the construction of a soft-release enclosure and post-release monitoring using radiotelemetry. We fitted animals with $17 \mathrm{~g}$ radio collars (BioTrack) and tracked them with a flexible Yagi antenna and receivers (Communications Specialists and PT Lotek). Animals were recaptured to remove collars before battery life ended. We intended to follow released animals for a minimum period of 3 mo to, preferably, 1 yr, unless death, sickness, or movement into an area too close to human habitation occurred.

\section{RESULTS}

\section{Demographics}

In 2008, the CPC began receiving slow lorises from the pet trade. Up until December 2011, 180 individuals were admitted. In the first 2 yr a large influx of slow lorises occurred, with admissions peaking at 82 individuals in 2009, but this was then followed by a sharp decline until 2011 (Fig. 1). The total number of slow lorises housed at the CPC steadily climbed until 2009 and remained stable until 2011 at around 95 individuals. Over a third $(\mathrm{n}=61)$ of all the slow lorises that arrived at the centre died. Mortality was highest in 2010, with 26 cases, and lowest in 2008, with 3 cases. Slow lorises surrendered to the CPC by the public over the 4 yr comprised $37 \%$ of all slow lorises received (Fig. 2). Slow lorises from government rescue facilities comprised $35 \%$. Confiscations that occurred in transit before animals reached markets comprised $21 \%$. Captive-born animals constituted $6 \%$. In 2009, CPC received significantly more slow lorises from confiscations than in other years $\left(\chi^{2}=\right.$ 59.3, df $=6, \mathrm{p}<0.001)$. N. javanicus from Java was the most common slow loris species received (55\% of the total), with $N$. coucang from Sumatra and $N$. menagensis from Borneo comprising 41 and $4 \%$, respectively (Fig. 3).

Prices of slow lorises bought in the markets ranged from 300000 to 1000000 Indonesian Rupiahs (approximately US\$ 33 to 109 at December 2011 exchange rates). Market traders often cut the teeth of slow lorises, using pliers, wire cutters, or nail clippers, to avoid being bitten when handling the ani-

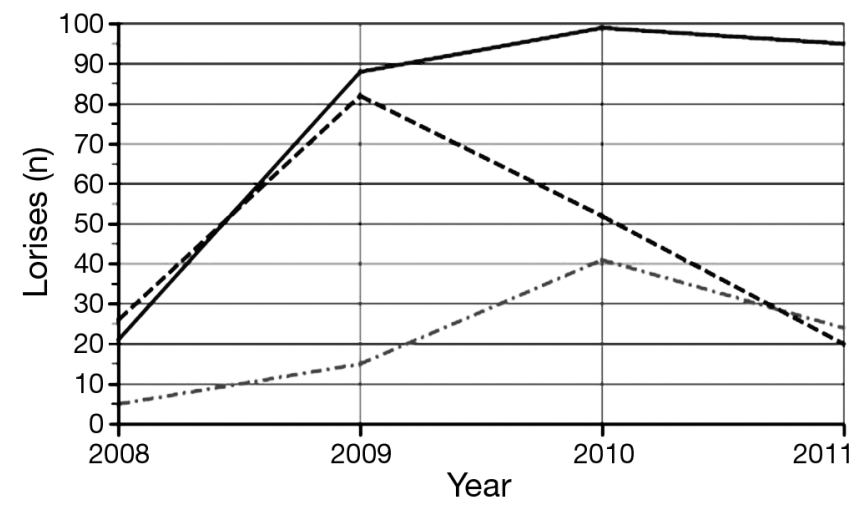

Fig. 1. Nycticebus spp. Slow lorises entering (thick dashed line) and exiting the Ciapus Primate Centre, Indonesia (dashed dotted line) and the running total of individuals (solid line) from 2008 to 2011. As expected, a high influx of animals is apparent in the first $2 \mathrm{yr}$, followed by a sharp decrease in numbers once full capacity has been reached 


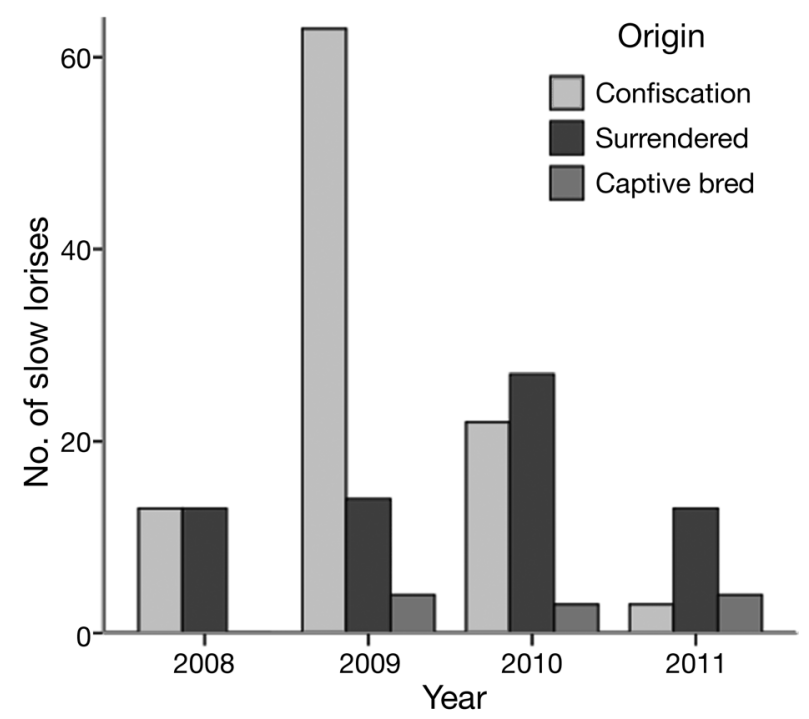

Fig. 2. Nycticebus spp. Counts of slow lorises admitted to the Ciapus Primate Centre, Indonesia, from 2008 to 2011 and their source of origin: confiscations, surrendered, transit, or captive-born

mals. Reconstructive-endodontic dental work was carried out on the affected slow lorises where possible, but often removal of the broken teeth was the only option. Of all slow lorises, $64 \%$ had their teeth damaged to some degree. Of slow lorises originating from the transit raids $100 \%$ had their teeth intact, or only partially cut. No significant differences were found between mortality rates (averaged over the

$4 \mathrm{yr})$ and (1) species $\left(\chi^{2}=0.195, \mathrm{df}=2, \mathrm{p}=0.91\right)$ or (2) origin $\left(\chi^{2}=3.44, d f=4, p=0.49\right)$. Females, however, had significantly higher mortality within the first year at the CPC than did males $\left(\chi^{2}=6.089\right.$, $\mathrm{df}=2, \mathrm{p}=0.05$ ).

\section{Translocations}

Twenty-three slow lorises were released after April 2010: $18 N$. javanicus and $5 N$. coucang. The $N$. javanicus were released into the Gunung HalimunSalak National Park, West Java, and the N. coucang were released into the Batutegi Nature Reserve, Lampung, Sumatra (Tables $1 \& 2$ ).

Of the 18 slow lorises released into the Gunung Halimun-Salak National Park, 6 died in the forest, 1 died at the CPC after it had been recaptured and 1 had her arm amputated and remains at the centre. One died of bacterial sepsis: during post-mortem examinations, septicaemia and military abscesses were found in the liver, lungs, spleen and lymph nodes. Bacterial cultures from post-mortem lesions isolated Klebsiella pneumonieae, an opportunistic pathogen that colonises and survives in affected organs (Quinn et al. 2011). This pathogen is generally found in individuals with a weakened immune system and is reported to be virulent in prosimians (Junge 2003). It is one of the most commonly isolated bacteria in post-mortem samples from slow lorises at the CPC. Another slow loris was

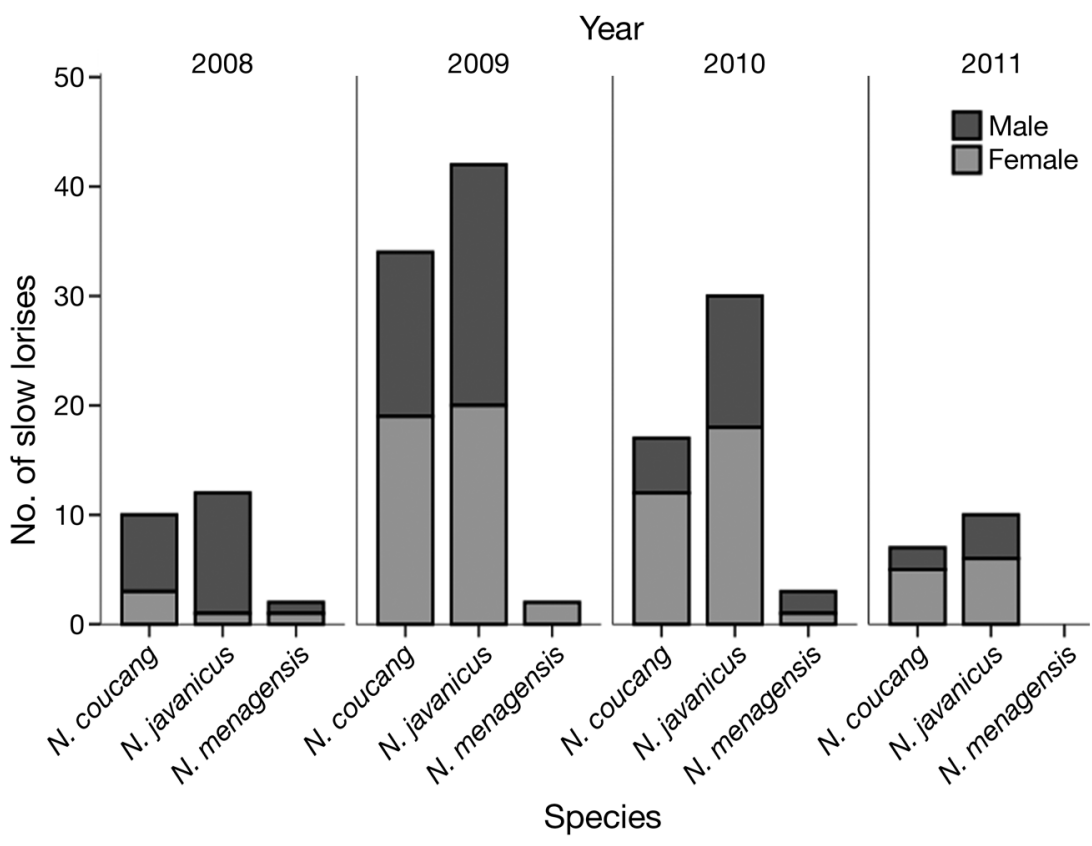

Fig. 3. Nycticebus spp. Counts of the 3 slow loris species admitted to the Ciapus Primate Centre, Indonesia, over 4 yr, by sex found dead on the forest floor and was suspected to have died of septicaemia. One of the lesions found during post-mortem macroscopic examination was pulmonary oedema, which is a build-up of abnormal fluids in the abdomen and is often caused by low protein in the blood. Possible causes of oedema include viral infections, hypersensitivity reactions and septicaemia. A third slow loris, considered to be an old individual, was returned to the clinic after release because of visible weakness. After further attempts to re-release, she was brought back to the centre owing to bad health, and died after a few months. Post-mortem changes indicated septicaemia. Various bacteria (Escherichia coli, Enterococcus sp. and Pseudomonas aeruginosa) were isolated from samples. Two died of 
Table 1. Nycticebus spp. Details and outcomes of the translocation of 18 Javan slow lorises from the Ciapus Primate Centre, Indonesia, released into the Gunung Halimun-Salak National Park, Java, Indonesia, between 2010 and 2013. M: male; F: female; (-) loris released without a habituation period in a cage

\begin{tabular}{|c|c|c|c|c|c|c|c|c|c|}
\hline No. & Sex & $\begin{array}{l}\text { Habituation } \\
\text { (d) }\end{array}$ & $\begin{array}{l}\text { Cage } \\
\text { type }\end{array}$ & $\begin{array}{l}\text { Date of } \\
\text { release }\end{array}$ & $\begin{array}{c}\text { Days } \\
\text { survived }\end{array}$ & $\begin{array}{l}\text { Reason for } \\
\text { rescue }\end{array}$ & $\begin{array}{l}\text { Reason for } \\
\text { termination }\end{array}$ & Status & $\begin{array}{c}\text { Cause of } \\
\text { death }\end{array}$ \\
\hline 1 & $\mathrm{M}$ & 5 & Small & 18 Apr 2010 & 16 & \multirow{3}{*}{ Entered village } & & Dead & \multirow[t]{2}{*}{ Unknown } \\
\hline \multirow[t]{2}{*}{2} & $\mathrm{~F}$ & 5 & Small & 18 Apr 2010 & 22 & & & Recaptured & \\
\hline & & 0 & - & 7 Jun 2010 & 10 & & & Dead & Unknown \\
\hline 3 & M & 7 & Small & 21 May 2010 & 61 & Weakness & & Dead & $\begin{array}{c}\text { Klebsiella } \\
\text { pneumoniae }\end{array}$ \\
\hline 4 & F & 7 & Small & 21 May 2010 & 27 & Entered village & & Dead & \\
\hline 5 & $\mathrm{~F}$ & 10 & Small & 30 Aug 2010 & 94 & \multirow{3}{*}{ Infection } & Collar irritation & Unknown & \\
\hline \multirow[t]{2}{*}{6} & $\mathrm{~F}$ & 50 & Small & 10 Nov 2010 & 31 & & & Recaptured & \multirow{4}{*}{$\begin{array}{c}\text { Unknown } \\
\text { Septicaemia }\end{array}$} \\
\hline & & 9 & Small & 28 Jan 2011 & 25 & & & Dead & \\
\hline 7 & $\mathrm{~F}$ & 85 & Small & 25 Feb 2011 & 12 & Weakness & & Dead & \\
\hline 8 & M & 16 & Small & 3 May 2011 & $365+$ & & & Alive & \\
\hline 9 & $\mathrm{~F}$ & 4 & Large & 26 Jun 2011 & 80 & \multirow{10}{*}{ Wounded } & Collar bitten off & Unknown & \multirow{10}{*}{ Electrocution } \\
\hline 10 & $\mathrm{M}$ & 104 & Large & 4 Oct 2011 & 118 & & & Dead & \\
\hline 11 & $\mathrm{~F}$ & 123 & Large & 12 Dec 2011 & 397 & & Collar battery end & Unknown & \\
\hline 12 & M & 9 & Large & 3 Jan 2012 & 409 & & Collar battery end & Unknown & \\
\hline 13 & $\mathrm{~F}$ & 120 & Large & 24 Mar 2012 & 148 & & Arm amputated & Alive in $\mathrm{CPC}$ & \\
\hline 14 & $\mathrm{~F}$ & 82 & Large & 14 Jun 2012 & 452 & & Collar battery end & Unknown & \\
\hline 15 & M & 58 & Large & 17 Sep 2012 & $382+$ & & & Alive & \\
\hline 16 & $\mathrm{M}$ & 59 & Large & 18 Jan 2013 & $259+$ & & & Alive & \\
\hline 17 & $\mathrm{~F}$ & 0 & - & 7 Mar 2013 & $180+$ & & & Alive & \\
\hline 18 & $\mathrm{~F}$ & 41 & Large & 12 Sep 2013 & $22+$ & & & Alive & \\
\hline
\end{tabular}

Table 2. Nycticebus spp. Details and outcomes of the translocation of 5 Sumatran slow lorises from the Ciapus Primate Centre released into the Batutegi Reserve in Lampung, Sumatra, Indonesia, between 2010 and 2013. M: male; F: female

\begin{tabular}{|c|c|c|c|c|c|c|c|c|}
\hline No. & Sex & $\begin{array}{l}\text { Habituation } \\
\text { (d) }\end{array}$ & $\begin{array}{l}\text { Cage } \\
\text { type }\end{array}$ & $\begin{array}{l}\text { Date of } \\
\text { release }\end{array}$ & $\begin{array}{c}\text { Days } \\
\text { survived }\end{array}$ & $\begin{array}{l}\text { Reason for } \\
\text { termination }\end{array}$ & Status & $\begin{array}{l}\text { Cause } \\
\text { of death }\end{array}$ \\
\hline 1 & M & 6 & Small & 27 Apr 2011 & 146 & Collar battery end & Unknown & \\
\hline 2 & $\mathrm{~F}$ & 121 & Large & 11 May 2012 & 157 & & Dead & Predation by snake \\
\hline 3 & $\mathrm{~F}$ & 52 & Large & 21 Aug 2012 & 62 & & Dead & Unknown \\
\hline 4 & M & 92 & Large & 30 Sep 2012 & 287 & & Dead & Predation by raptor? \\
\hline 5 & $\mathrm{~F}$ & 90 & Large & 2 Apr 2013 & 9 & & Dead & Predation by snake \\
\hline
\end{tabular}

unknown causes (owing to the rapid decomposition of the cadavers in the hot and humid forest conditions despite their retrieval after approximately $3 \mathrm{~d}$ ). For this reason, post-mortem examinations were not possible; no visible signs of predation were evident.

Three slow lorises survived until the end of the monitoring period, after which the collars were removed. Monitoring of 2 slow lorises was cut short because of collar irritation, whereby the collar was subsequently removed, and, in 1 incidence, the collar was bitten off by another slow loris; the previous night the released slow loris had been observed grooming with an uncollared slow loris and the following morning the collar was found chewed open and displaying small teeth marks. Both slow lorises had been active and feeding regularly prior to the loss of collars. For all 5 of these released slow lorises it is not known whether or not they are still alive. Five slow lorises are currently under observation (as of December 2013), 2 of these have survived longer than a year.

Of the 5 greater slow lorises released into the Batutegi Reserve, 1 survived until the end of the monitoring period, 3 fell victim to predation and 1 died of unknown causes. Predation by snakes was confirmed, as the collars were later retrieved from the snakes once they had been excreted. Predation by a raptor was suspected as only the head and collar of the slow loris was found.

When all releases are considered, no significant associations were found between any measures taken to ensure success or length of survival. In Javan slow lorises, there was a significant association between size of habitation cage and survival success (Mann-Whitney $U$-test, $U=11.5$, p $<0.02$ ), with longer survival for individuals that had access to larger habituation cages. 


\section{DISCUSSION}

Demographic data from the CPC reveal a rapid increase in slow lorises admitted to the centre in the first $2 \mathrm{yr}$, and then a steep decline in 2010 and 2011. This trend is consistent with predictions by Nijman (2009) and Teleki (2001) who suggest that an initial peak in animals taken in occurs until capacity is reached-in approximately $2 \mathrm{yr}$-followed by a rapid decline. Indeed, after reaching full capacity, the $\mathrm{CPC}$ reduced numbers of slow lorises being received owing to space restrictions. Mortality was lowest in 2008, with 3 deaths, and highest in 2010, with 25. These occurrences can probably be attributed to the lower numbers of animals housed in 2008 compared to successive years. With more slow lorises housed, parasites and disease have a higher likelihood of spreading (Bernacky et al. 2002). Slow lorises deriving from transit raids arrived with fewer damaged teeth than those from markets, suggesting that the teeth clipping procedure occurred at or after arrival at markets. Of the slow lorises at the CPC, $64 \%$ have had their teeth severely or completely cut and are thus unsuitable candidates for translocation, owing to difficulties in feeding on certain harder bodied food items such as gum, small reptiles and large arthropods (Starr \& Nekaris 2013).

Despite a detailed reintroduction programme by $\mathrm{CPC}$, the initial results mirror numerous other translocation attempts with mixed survival success (Kleiman et al. 1986, Bennett 1992, Streicher 2004). That said, survival success in slow lorises released into Gunung Halimun-Salak has improved slightly. The move to a larger habitation cage appears to have had a positive impact on survival success in Javan slow lorises. Both the stress of transport to the release site and the novelty of the release site are stress factors that can increase the vulnerability of individuals and decrease the chances of translocation success (Dickens et al. 2010). The large (50 m perimeter) open-top cage situated at the release site provides an opportunity for the slow lorises to acclimatise to the new release environment and allows time to recover from the stress of transportation. This 'soft release' or 'delayed-release' technique has been found to influence success in translocations in other species (Bradley et al. 2005, Parker et al. 2008), but not in all cases (Hardman \& Moro 2006), and suggests that certain successful techniques are often species or site specific.

The low success rates, as well as cost and labour intensity, in translocation programmes are one of the arguments against their usefulness in conservation plans (Fischer \& Lindenmayer 2000). Animals currently housed in rescue centres around the world, many of which are globally threatened, could, potentially, offer the last chance to save species through captive breeding and translocation (Trayford \& Farmer 2012). We now discuss alternatives to the question raised earlier: What is the most viable option regarding compassionate conservation (Bekoff 2013a) for animals that cannot be released?

\section{Euthanasia}

Euthanasia involves humanely terminating the life of an animal for its own benefit (Broom 2007). Thousands of animals are euthanized on a yearly basis by humane societies to reduce animal suffering, but also owing to lack of space for suitable housing (Harcourt 1987, Bennett 1992, AVMA 2001, Wickins-Dražilová 2006). When euthanising healthy or unwanted animals, serious consideration must be given to relevant ethical issues (Bennett 1992, AVMA 2001).

Laws on euthanasia differ between and even within countries (AVMA 2001, Bacon 2008, Julien et al. 2010). Depending on local cultures and religions, euthanasia can be met with hostility and is a controversial option (Bennett 1992, Ware 2001, Bacon 2008). Numerous animal rights groups oppose euthanasia, especially of healthy individuals, and actively encourage the public to oppose this practice (Miller 2007).

Further controversy regarding euthanasia arises when rescued animals are threatened with extinction. Some conservationists believe that practising euthanasia limits conservation opportunities for restocking dwindling wild populations (Harcourt 1987, Carter 2003, Beck 2010). Some contend that euthanasia may be a more favourable option than captivity. Especially for those animals kept in small crowded cages, in unnatural social groups and with no chance to reproduce, captivity can be deemed stressful and inhumane (Bennett 1992, Rosen \& Byers 2002).

Restrictions on conducting euthanasia can also create problems indirectly, in the form of overcrowding. Typically, rescue centres receive animals on a firstcome-first-served basis, do not discriminate between sex or age and rarely employ a triage system, whereby animals with mental or physical deficiencies or possessing minimal chance of socialisation or rehabilitation are rejected (Teleki 2001). Consequently, rescue centres can fill up with animals unfit for release (Teleki 2001, Rosen \& Byers 2002). A res- 
cue centre at capacity is not a problem in itself if sufficient funds are available to ensure adequate welfare. A dilemma arises if other potentially fit and releasable animals must be refused because of lack of space. The rejection of animals is a difficult decision to make, yet necessary for maintaining the welfare of animals already housed (Cheyne 2006). Such actions may, consequently, result in a fraying of relations or bad publicity between the rescue centre and their corresponding authorities and funding agencies (Knowles 1986, Beck et al. 1994, Bacon 2008).

\section{Captivity}

In situations where neither release nor euthanasia are appropriate, housing an animal indefinitely is the only other option (Carter 2003, Russon 2009). This can be either in the rescue centre itself or the animal can be transferred to another type of captive facility. Welfare considerations need to be addressed, including: knowledge of the animal's ecological and behavioural needs; suitable facilities to accommodate these and house the animal humanely; an assessment of the risk of disease transmission; justification for keeping the animal in captivity regarding its value in conservation education and research; justification of costs related to ensure welfare through suitable housing, feeding, environmental enrichment and veterinary care (Bennett 1992, Cooper \& Cooper 2006).

An important issue regarding the housing of confiscated animals in rescue centres and zoos is whether it, in fact, contributes to illegal trade. The trade can be exacerbated when members of the public purchase the animal out of pity and then surrender it to a nearby facility (Harcourt 1987, Karesh 1995, Farmer \& Courage 2008, Beck 2010). Additionally, rescue centres and zoos create a humane outlet for the confiscated animals and thereby potentially reduce the pressure on governments to deal with perpetrators (Harcourt 1987, Cuarón 2005, Sumrall 2009).

Enforcement of environmental laws is normally dealt with by governments, and the allocation of funds to this cause is often limited (Cuarón 2005), which prompts the question: Would available funding for housing confiscated animals be better utilised in the prevention of trade in lieu of dealing with the after-effects (Bennett 1992, Ware 2001, Cheyne 2006)? Leighton \& Whitten (1984) argue that illegal trade is actually reduced by the establishment of rescue centres and suggest that as confiscations increase, trade will decline. In Indonesia, for example, there is an ostensible relationship between rescue centres receiving displaced gibbons and the frequency of confiscations taking place. As rescue centres reach capacity, a reduction in confiscations is observed (Nijman 2009, Nijman et al. 2009). Logically, only when confiscations are backed up sufficiently by local authorities ensuring perpetrators always face legal penalties, can rescue centres help in directly quelling the trade (André et al. 2008, Beck 2010). Most zoos and rescue centres are limited in the numbers of animals they can receive, owing to finite resources, managing to humanely house only a fraction of those animals (Knowles 1986, Bennett 1992, Ware 2001, Cuarón 2005).

\section{Translocations}

The IUCN Reintroduction Specialist Group defines a translocation as

the human-mediated of living organisms from one area, with release in another (IUCN 2012, p. 2)

We practised conservation translocation, which is

the deliberate movement of organisms from one site for release in another. It must be intended to yield a measurable conservation benefit at the levels of a population, species or ecosystem, and not only provide benefit to translocated individuals; conservation translocations include reinforcement and reintroduction within a species' indigenous range (IUCN 2012, p. 12)

The principal justifications for translocation appear to be 4-fold: for the conservation benefits of reintroducing or restocking endangered populations (MacKinnon \& MacKinnon 1991, Stanley Price \& Soorae 2003), from a welfare perspective in giving the animals the freedom they deserve (Albrecht 2003, Swaisgood 2010), to resolve human-wildlife conflicts (Fischer \& Lindenmayer 2000) and for translocating animals to relieve overcrowding in captivity (Bennett 1992, Beck 2010, IUCN/SSC 2013).

In recent years, translocation of animals within their native habitat has been commonly employed as a conservation tool for combatting biodiversity loss (MacKinnon \& MacKinnon 1991, Mathews et al. 2005). Translocation programmes are renowned for being problematic, with low success rates, and are extremely costly (Seddon et al. 2005, Beck 2010). Some critics argue that translocations are a waste of valuable funding (see Bennett 1992, Ware 2001, Wickins-Dražilová 2006, Beck 2010). Successful translocations have been achieved (e.g. Beck et al. 1994, Fischer \& Lindenmayer 2000), and, if conducted correctly with minimal risks, translocation 
remains the only viable option for the increasing numbers of displaced threatened animals (Carter 2003, Cheyne 2006, Beck 2010, Cheyne et al. 2012).

The potential viability of translocations has been extensively covered elsewhere (Fischer \& Lindenmayer 2000, Stanley Price \& Soorae 2003, Faria et al. 2010). As long as animals are hunted, displaced, or traded there will continue to be animal refugees; organisations, both conservation and animal welfare, will continue to conduct translocations (Ware 2001). Whilst conservationists see translocation as a means of conserving populations, welfare groups see translocation as a means of helping individual animals have a chance to live in the wild again (Albrecht 2003, Wickins-Dražilová 2006, Swaisgood 2010). Either way, both parties should be conducting the same procedures to ensure success (Bekoff 2013b).

The release of an animal back into the wild, one that has been the victim of trade and is otherwise faced with either a lifetime in captivity or euthanasia, may appear the ethically correct action to take (Albrecht 2003, Wickins-Dražilová 2006). Caution is needed that we are not merely conducting releases for the purpose of human gratification (Albrecht 2003). Although issues of welfare in the context of captivity and euthanasia are often raised in the literature (see Glatston 1998, Clubb \& Mason 2003, Hosey 2005, Mallapur 2005, Broom 2007), these issues rarely appear in association with translocations. For organisations conducting translocations, release of an animal can yield a sense of success and fulfilment. For the animal, however, being released into the wild is not necessarily the most compassionate option (Yeager \& Silver 1999). Released into an unknown habitat the animal is suddenly forced to contend with predators, aggressive conspecifics defending their territories and the finding of sufficient and appropriate food ${ }_{1}$ all of which may lead to a slow and painful death from attacks, starvation, or stress-induced diseases (Yeager \& Silver 1999, Beck 2010). Post-release monitoring of animals allows surveillance of survival and has consistently revealed high mortality (Bennett 1992). If the animals released just slowly deteriorate and die, this option is analogous to killing them (Harcourt 1987), and perhaps euthanasia would be more humane.

Further consideration of the welfare and conservation implications of the ecosystem at the release site is also necessary (Osborne \& Seddon 2012). Releasing an animal into an already stable habitat may potentially disrupt the balance of the ecosystem and to threaten other species of flora and fauna through competition, predation, or transfer of disease
(Burgman et al. 1998, Yeager \& Silver 1999, Teleki 2001, Beck 2010). Whether releasing an animal is actually more detrimental to the ecosystem as a whole needs to be addressed. Only through the selection of suitable and sustainable habitats, supplemented with long-term, post-release monitoring, can this be determined (Cheyne 2009). Furthermore, protection of the habitat should be ensured prior to release. If the habitat is not fully protected and the animal is re-captured by hunters, all the effort and cost involved in the project are wasted-and the trade is carelessly exacerbated (Wickins-Dražilová 2006).

Despite their apparently conflicting views, it is evident that the goals of conservation biologists and welfare scientists show substantial convergence (Beausoleil et al. 2014). Whilst the methods and motivations may differ, the overall outcome - whether it is to ensure the welfare of an individual or the conservation of a species - is ironically often dependent on a more synthesised approach to succeed (Bekoff 2013a). Maintaining the welfare of an animal in the wild is reliant on conservation efforts to protect its habitat. Conversely, when conservation initiatives fail to conserve and protect habitats, the last chance for many threatened species may derive from the thousands of animals that welfare centres currently house. Through the instigation of compassionate conservation, the conservation and welfare of species and individuals may be better achieved.

Acknowledgements. We thank the Indonesian Institute of Sciences and International Animal Rescue. Assistance was provided by K. Llano Sanchez, S. Paramasivam, B. Muhidin, M. Jakaria, M. Enda, D. Firman and B. Acong. H. Hilser, V. Nijman, C. Starr and 2 anonymous reviewers greatly improved the quality of this manuscript, and T. King provided valuable literature. International Animal Rescue, Ocean Park Conservation Foundation Hong Kong, Leverhulme Trust (RPG-084) and the Primate Society of Great Britain Captive Care provided funding.

\section{LITERATURE CITED}

Albrecht G (2003) Rehabilitation and introduction of captive wildlife. In: Armstrong SJ, Botzler RG (eds) The animal ethics reader. Routledge, London, p 422-425

André C, Kamate C, Mbonzo P, Morel D, Hare B (2008) The conservation value of Lola ya Bonobo Sanctuary. In: Furuichi T, Thompson J (eds) The Bonobos. Springer, New York, NY, p 303-322

AVMA (American Veterinary Medicine Association) (2001) Report of the AVMA panel on euthanasia. J Am Vet Med Assoc 218:669-696

Bacon H (2008) Challenges of charity veterinary work in developing countries. In Pract 30:412-415 
Beausoleil NJ (2014) Balancing the need for conservation and the welfare of individual animals, Chap 8. In: Appleby MC, Weary DM, Sandøe P (eds) Dilemmas in animal welfare. World Society for the Protection of Animals, London, p 124

Beck BB (2010) Chimpanzee orphans: sanctuaries, reintroduction, and cognition. In: Lonsdorf E, Ross SR, Matsuzawa $\mathrm{T}$, Goodall $\mathrm{J}$ (eds) The mind of the chimpanzee: ecological and experimental perspectives. University of Chicago Press, Chicago, IL, p 332-346

Beck BB, Rappaport LG, Stanley Price MR, Wilson AC (1994) Reintroduction of captive-born animals. In: Olney PJS, Mace GM, Feistner A (eds) Creative conservation: interactive management of wild and captive animals. Chapman \& Hall, London, p 265-286

Bekoff M (2013a) Ignoring nature no more: the case for compassionate conservation. University of Chicago Press, Chicago, IL

Bekoff M (2013b) Compassionate conservation and the ethics of species research and preservation: hamsters, black-footed ferrets, and a response to Rob Irvine: comment on "ethics of species research and preservation" by Rob Irvine. J Bioeth Inq 10:527-529

Bennett J (1992) A glut of gibbons in Sarawak-Is rehabilitation the answer? Oryx 26:157-164

Bernacky BJ, Gibson SV, Keeling ME, Abee CR (2002) Non human primates. In: Fox JG (ed) Laboratory animal medicine. Academic Press, New York, NY, p 676-777

Bradley EH, Pletscher DH, Bangs EE, Kunkel KE and others (2005) Evaluating wolf translocation as a nonlethal method to reduce livestock conflicts in the northwestern United States. Conserv Biol 19:1498-1508

Broom DM (2007) Quality of life means welfare: How is it related to other concepts and assessed? Anim Welf 16: 45-53

Burgman MA, Lindenmayer D, Drill C (1998) Conservation biology for the Australian environment. Surrey Beatty \& Sons, Adelaide

Carter J (2003) Orphan chimpanzees in West Africa: experiences and prospects for viability in chimpanzee rehabilitation. In: Kormos R, Boesch C, Bakarr MI (eds) West African chimpanzees. IUCN, Gland, p 157-167

Cheyne SM (2006) Wildlife reintroduction: considerations of habitat quality at the release site. BMC Ecol 6:5

Cheyne SM (2009) The role of reintroduction in gibbon conservation: opportunities and challenges. In: Lappan S, Whittaker DJ (eds) Gibbons. New perspectives on small ape socioecology. Springer, New York, NY, p 477-496

Cheyne SM, Campbell CO, Payne KL (2012) Proposed guidelines for in situ gibbon rescue, rehabilitation and reintroduction. Int Zoo Yearb 46:265-281

Clubb R, Mason G (2003) Animal welfare: captivity effects on wide-ranging carnivores. Nature 425:473-474

Cooper J, Cooper ME (2006) Ethical and legal implications of treating casualty wild animals. In Pract 28:2-6

> Cuarón AD (2005) Further role of zoos in conservation: monitoring wildlife use and the dilemma of receiving donated and confiscated animals. Zoo Biol 24:115-124

Dickens MJ, Delehanty DJ, Michael Romero L (2010) Stress: an inevitable component of animal translocation. Biol Conserv 143:1329-1341

Faria PJ, van Oosterhout C, Cable J (2010) Optimal release strategies for captive-bred animals in reintroduction programs: experimental infections using the guppy as a model organism. Biol Conserv 143:35-41
Farmer KH, Courage A (2008) Sanctuaries and reintroduction: a role in gorilla conservation. In: Stoinski TS, Steklis HD, Mehlman pT (eds) Conservation in the $21^{\text {st }}$ century: gorillas as a case study. Springer, New York, NY, p 79-106

Fischer J, Lindenmayer DB (2000) An assessment of the published results of animal relocations. Biol Conserv 96: 1-11

Fraser D (1999) Animal ethics and animal welfare science: bridging the two cultures. Appl Anim Behav Sci 65: 171-189

Glatston AR (1998) The control of zoo populations with special reference to primates. Anim Welf 7:269-281

Harcourt AH (1987) Options for unwanted or confiscated primates. Primate Conserv 8:111-113

- Hardman B, Moro D (2006) Optimising reintroduction success by delayed dispersal: Is the release protocol important for hare-wallabies? Biol Conserv 128:403-411

Hosey GR (2005) How does the zoo environment affect the behaviour of captive primates? Appl Anim Behav Sci 90: 107-129

IUCN (International Union for the Conservation of Nature) (2002a) Guidelines for nonhuman primate reintroductions. In: Soorae PS, Baker LR (eds) Re-introduction news. IUCN/SSC Re-introduction Specialist Group, Cambridge, p 29-57

IUCN (2002b) Guidelines for the placement of confiscated animals. IUCN/SSC Re-introduction Specialist Group, Cambridge

IUCN/SSC (International Union for the Conservation of Nature/Species Survival Commission) (2012) Guidelines for re-introductions and other conservation translocations (Version 1.0). IUCN/SSC, Gland

Julien TJ, Vantassel SM, Groepper SR, Hygnstrom SE (2010) Euthanasia methods in field settings for wildlife damage management. Human Wildl Interact 4:158-164

Junge RE (2003) Prosimians. In: Fowler ME, Miller RE (eds) Zoo and wild animal medicine. Elsevier Saunders, Philadelphia, PA, p 334-346

Kabasawa A (2011) The chimpanzees of West Africa: from 'man-like beast' to 'our endangered cousin'. In: Matsuzawa T, Humle T, Sugiyama Y (eds) The chimpanzees of Bossou and Nimba. Springer, Tokyo, p 45-57

Karesh WB (1995) Wildlife rehabilitation: additional considerations for developing countries. J Zoo Wildl Med 26: 2-9

Kleiman DG, Beck BB, Dietz JM, Dietz LA, Ballou JD, Coimbra-Filho AF (1986) Conservation program for the golden lion tamarin: captive research and management, education and reintroduction. In: Benirschke F, Morris P (eds) Primates: the road to self-sustaining populations. Springer, New York, NY, p 959-979

Knowles JM (1986) Wild and captive populations: triage, contraception and culling. Int Zoo Yearb 24:206-210

Leighton DR, Whitten AJ (1984) Management of free-ranging gibbons. In: Preuschoft $\mathrm{H}$, Chivers DJ, Brockelman WY, Creel N (eds) The lesser apes: evolutionary and behavioural biology. Edinburgh University Press, Edinburgh, p 32-43

MacKinnon J (1977) The future of orang-utans. New Sci 74 : $697-699$

MacKinnon K, MacKinnon J (1991) Habitat protection and reintroduction programmes. In: Gipps JH (ed) Beyond captive breeding: re-introducing endangered mammals to the wild. Clarendon Press, Oxford, p 173-196 
Mallapur A (2005) Managing primates in zoos: lessons from animal behaviour. Curr Sci 89:1214-1219

Mathews F, Orros M, McLaren G, Gelling M, Foster R (2005) Keeping fit on the ark: assessing the suitability of captive-bred animals for release. Biol Conserv 121:569-577

Miller JE (2007) Evolution of the field of wildlife damage management in the United States and future challenges. Human Wildl Interact 1:13-20

Munds RA, Nekaris KAI, Ford SM (2013) Taxonomy of the Bornean slow loris, with new species Nycticebus kayan (Primates, Lorisidae). Am J Primatol 75(1): 46-56

Nekaris KAI, Sanchez KL, Thorn JS, Winarti I, Nijman V (2009) Javan slow loris. In: Mittermeier R (ed) Primates in peril: the world's top 25 most endangered primates 2008-2010. Conservation International, Arlington, VA, p 44-46

Nekaris KAI, Starr CR, Shepherd CR, Nijman V (2010) Revealing culturally-specific patterns in wildlife trade via an ethnoprimatological approach: a case study of slender and slow lorises (Loris and Nycticebus) in South and Southeast Asia. Am J Primatol 72:877-886

Nijman V (2009) An assessment of trade in gibbons and orang-utans in Sumatra, Indonesia. TRAFFIC Southeast Asia, Petaling Jaya

> Nijman V (2010) An overview of international wildlife trade from Southeast Asia. Biodivers Conserv 19:1101-1114

> Nijman V, C-F Martinez, Shepherd CR (2009) Saved from trade: donated and confiscated gibbons in zoos and rescue centres in Indonesia. Endang Species Res 9: 151-157

Nijman V, Nekaris KAI, Donati G, Bruford M, Fa J (2011) Primate conservation: measuring and mitigating trade in primates. Endang Species Res 13:159-161

Osborne PE, Seddon PJ (2012) Selecting suitable habitats for reintroductions: variation, change and the role of species distribution modelling. In: Ewen JG, Armstrong DP, Parker KA, Seddon PJ (eds) Reintroduction biology: integrating science and management. Oxford, WileyBlackwell, p 73-104

Parker ID, Watts DE, Lopez RR, Silvy NJ, Davis DS, McCleery RA, Frank PA (2008) Evaluation of the efficacy of Florida Key deer translocations. J Wildl Manag 72: 1069-1075

Quinn PJ, Markey BK, Leonard FC, FitzPatrick ES, Fanning S, Hartigan PJ (2011) Veterinary microbiology and microbial disease. Wiley-Blackwell, Chichester

Ramp D (2013) Bringing compassion to the ethical dilemma in killing kangaroos for conservation. J Bioeth Inq 10: 267-272

Reading RP, Miller B, Shepherdson D (2013) The value of enrichment to reintroduction success. Zoo Biol 32: 332-341

Rijksen HD, Meijaard E (1999) Our vanishing relative: the status of wild orang-utans at the close of the twentieth century. Kluwer Academic Publishers, Dordrecht

Rosen N, Byers O (2002) Orangutan Conservation and Reintroduction Workshop: final report. IUCN/SSC Captive Breeding Specialist Group, Apple Valley, MN
Russon AE (2009) Orangutan rehabilitation and reintroduction. In: Wich SA, Utami SS, Mitra Setia T, van Schaik CP (eds) Orangutan. Oxford University Press, Oxford, p 327-350

> Seddon PJ, Soorae PS, Launay F (2005) Taxonomic bias in reintroduction projects. Anim Conserv 8:51-58

> Seddon PJ, Armstrong DP, Maloney RF (2007) Developing the science of reintroduction biology. Conserv Biol 21: 303-312

Seddon PJ, Strauss WM, Innes J (2012) Animal translocations: What are they and why do we do them? In: Ewen JG, Armstrong DP, Parker KA, Seddon PJ (eds) Reintroduction biology: integrating science and management. Wiley-Blackwell, Oxford, p 1-32

> Shepherd CR (2010) Illegal primate trade in Indonesia exemplified by surveys carried out over a decade in North Sumatra. Endang Species Res 11:201-205

Shepherd CR, Sukumaran J, Wich SA (2004) Open season: an analysis of the pet trade in Medan, North Sumatra, 1997-2001. TRAFFIC Southeast Asia, Petaling Jaya

Soorae PS (2008) Global re-introduction perspectives. IUCN/SSC Re-introduction Specialist Group, Abu Dhabi

Stanley Price MR, Soorae PS (2003) Reintroductions: whence and whither? Int Zoo Yearb 38:61-75

Starr C, Nekaris KAI (2013) Obligate exudativory characterizes the diet of the pygmy slow loris Nycticebus pygmaeus. Am J Primatol 75(10):1054-1061

Starr CR, Nekaris KAI, Streicher U, Leung LKP (2010) Traditional use of slow lorises Nycticebus bengalensis and $N$. pygmaeus in Cambodia: an impediment to their conservation. Endang Species Res 12:17-23

Streicher U (2004) Aspects of the ecology and conservation of the pygmy loris Nycticebus pygmaeus in Vietnam. $\mathrm{PhD}$ thesis, Ludwig-Maximilians Universität, Munich

Sumrall KA (2009) Confronting illegal wildlife trade in Vietnam: the experience of education for nature - Vietnam. $\mathrm{PhD}$ thesis, University of Michigan, Ann Arbor, MI

Swaisgood RR (2010) The conservation-welfare nexus in reintroduction programmes: a role for sensory ecology. Anim Welf 19:125-137

Teleki G (2001) Sanctuaries for ape refugees. In: Beck BB (ed) Great apes \& humans: the ethics of coexistence. Smithsonian Institution Press, Washington, DC, p 133-149

Trayford HR, Farmer KH (2012) An assessment of the use of telemetry for primate reintroductions. J Nature Conserv 20(6):311-325

Ware D (2001) Gibbon rehabilitation and reintroduction: the problems along the road before use as a viable conservation tool. In: The apes: challenges for the 21st century: conference proceedings Chicago Zoological Society, Brookfield, IL, p 259-261

Wickins-Dražilová D (2006) Zoo animal welfare. J Agric Environ Ethics 19:27-36

Yeager CP, Silver SC (1999) Translocation and rehabilitation as primate conservation tools: Are they worth the cost? In: Dolhinow P, Fuentes A (eds) The nonhuman primates. Mayfield Publishing, Mountain View, CA, p 164-169

Submitted: August 1, 2013; Accepted: May 28, 2014 Proofs received from author(s): October 7, 2014
Editorial responsibility: Brendan Godley, University of Exeter, Cornwall Campus, UK 